\title{
Genetics and the Legal Conception of Self
}

Isabel Karpin

Much feminist legal scholarship has attempted to critique the legal concept of selfhood for its reliance upon an artifice of physical boundedness and unity. Feminists who reject the law's embrace of a self produced in response to what Lacan called the "lure of spatial identification"1 (Lacan 1977: 5; Meek 1998) do so because the political, social, and legal consequences that follow from this ascription of selfhood work against the bodies of women. Women's bodies, it is argued, are least able to conform to an optics of the skin, particularly in the context of pregnancy. Unbounded corporeality is not however, confined to women's bodies. Haraway, for instance, points out that in these days of biotechnological seeing, "even the most reliable Western individuated bodies . . neither stop nor start at the skin, which is itself something of a teeming jungle threatening illicit fusions" (Haraway 1991: 215). The self is a construct that extends beyond the limits of the physical by simply being in the world. Its extension in time and space undermines the alleged autocracy of the individual. Susan Ballard argues, "every act of viewing becomes an event in which the boundaries of our bodies are imbricated in relations with other bodies" (Ballard 2001: 1). Similarly, Avital Ronell argues that once the telephone enabled the distant projection of the voice in space, the boundaries that demarcated our bodies were fundamentally questioned (Ronell 1989; see also Ronell 1994). In this chapter I want to show how genetic discourses, indifferent to the surface of the body as a marker of identity, demand a more complex understanding of the self in law. What happens, for instance, when genetic discourses reveal that we are all "leaky," boundaryless, and transgressive? 
In her discussion of conjoined twins, Margrit Shildrick describes the leakiness of self as corporeal ambiguity. She says: "[a]bove all it is the corporeal ambiguity and fluidity, the troublesome lack of fixed definition, the refusal to be either one thing or the other, that marks the monstrous as a site of disruption" (Shildrick 1999: 78). I will argue in a related approach that biogenetic discourses, which emphasize shared identity and participation in the common genetic pool, reveal the monstrousness in all of us. This is challenging to law because such discourses expose the impossibility of the autonomous, self-sufficient individual of liberal legalism. The individual in the age of the gene is fundamentally connected and vulnerable. The individual in the age of the gene always contains a trace of the other; not-one but not-two (Karpin 1992).

I turn to the normative individual of liberal jurisprudence and show how even he (and I use the gendered pronoun deliberately) can no longer sustain the essential distance and difference between one and another (Callois 1987). Allen Meek writes of how Lacan extrapolated from Callois's writing to explain that "the autonomous self is produced as an optical effect as a body attempts to conform to an encoded visual surface and to inhabit a landscape constituted as a field of the other's gaze" (Meek 1998: 3) It is this differentiated self, certain of its limits, that we are taught to prize. The failure to articulate and determine fixed and impenetrable boundaries is a failure of selfhood. The discourse of genetics requires us to lose ourselves (or more correctly to find ourselves) in a genetic code that imbricates us with the other. In this case we recognize a selfhood that is based on interconnection and intermingled identity.

In this chapter I examine both legislative and quasi-legislative attempts to restore the visual surface of the body as the marker of individual identity. In the case of genetic discourses, the primary means by which this has occurred is through privacy legislation. Such legislation aims to secure one's right to keep one's genetic identity to oneself. The problem is how to identify the rights-bearing individual in the first place. Each person's genetic code reveals not only who we are but also who else we might become. If we are always implicated in the genetic profiles of our relatives, can we hope to keep ourselves private and can it offer us any solace to do so? We share our genes with others by decreasing degrees of exactitude reaching out from the familial and ending in the common genetic pool of the species. Individuality then is the recognition of ourselves in others. "He has my eyes."

Genetic discourses reveal the individual in biomedical moments of self recognition in the other. They do not do away with individuality but to others. In They suggest that what makes us individual also joins us of selfhood. This righer, the liberal subject is still the preeminent mode those moments rights-bearing subject finds its greatest recognition in defining moments that carry with the by others. These are boundary. and autonomy-but the kind of them the promise of invulnerability interest. It is no surprise then autonomy that is characterized by selfat asserting themselves are that in this frame those most successful economic, cultural, and political resource have garnered sufficient social, indistinction, dependencies, and resources to minimize the impact of their do reside within these indivind interconnections. Bodily transgressions where they appear valueneuts, but they are accommodated to a point to be reified in their faventral, enabling the façade of independence that incorporates care, responsibility who demand an autonomy of self immersion with the messy, mixed-up failures. Heen as a definitional paradox-transgressive, which law, social, and biowever, it is this conception of self around ensure equality and justice.

\section{My aim here then,}

about the stability of liberal identity getic discourses to generate anxiety themselves at the margins with the rest that its current beneficiaries find norm of transgressivity. Law, in this of us. To do this, I posit a legal a subject that is inevitably connected, vulneme, must take as its base unit the transgressive is by definition thalnerable, and dependent. Because normative transgressivity is both that which goes beyond the limits, of being. (In being you I am me In oxymoron and a standard state having you I am free.) Genetic discour

tional conceptualization, are creating new tensions within the tradiaround or out of a biogenetically autonomous individual constructed Finkler and legal theorist Janet Dolgin raise family. Anthropologist Kara 
of the individual to a family that is constructed or mapped over a genetic pedigree. $^{3}$ This form of individuality, which immediately connects one to genetically related others, disables the liberal individual premised on a distinct and separate selfhood. Instead, it enables or renders able-bodied a transgressive individual whose very selfhood is already connected and vulnerable to the embodiment of someone else. I argue that this is not the end of individuality or indeed autonomy, but that transgressive selfhood demands of us a new understanding of each of these two terms. Before I make this argument, however, it is useful to use both Finkler and Dolgin's concerns as a stepping-off point.

Finkler argues that the hegemony of the gene is undermining what she describes as the "mark of a modern individual" namely, "autonomy, independence and detachment from kinship ties" (Finkler 2001: 237). Her focus is on the way that the gene reestablishes kinship as a biogenetic connection rather than a relationship established on the basis of choice. She states:

Beyond issues associated with gender, family and kinship ties have been given a new dimension that stresses faulty genes rather than social status, position or even poverty. Cultural significance is given to genetic transmission for better or for worse. (Finkler 2001: 239)

Finkler bases her argument on research she conducted involving several adoptees who sought out the identity of their birth parents. Many of them were motivated by a need to ascertain their medical histories. Others found themselves seeking out genetic relatives because they suffered from a genetically inherited form of disease (Finkler 2001). ${ }^{4}$ In examining these cases Finkler argues that the geneticization of kinship" has given rise to the possibility of a connection between individuals who may otherwise be nonintimate relations or strangers.

Although Finkler never expressly identifies what is wrong or right with these new directions, the language that she uses suggests that there are significant benefits in the biogenetic model of kinship. She says:

It recasts our dispersed and loose kinship ties as inexorable genetic ones and reestablishes our continuity with family and kin. Once uprooted we have been reunited by the medicalization of family and kinship. Willingly or not, we must recognize our connectedness, albeit by our dysfunction and disorders. DNA joins the compartmentalized, fragmented postmodern individual to his or her ancestors. (Finkler 2001: 249)
However, while Finkler reads the move back to connectedness as a cure to be aware of America and other western a modernist construction nations is for law the liberal individual, connections and enable determined to fend off intrusions and interthreat of incursion by others or unwillincy that promises selfhood. The of postmodern indistinction. transgressive, and it is what

Dolgin Iaments the prim Janet Dolgin finds so troubling.

modern "family of choice," suggesting that biogenetic family over the new individuality and autonomy. According that it results in the demise of both is being surpassed and in its placerding to Dolgin, the family-by-choice recourse to the intimacies of ace a new family entity is created without the "genetic family." Its coalitions are relationships. She terms this entity genealogies, which offer the knowledge across gene lines and shared of disease. As Dolgin describes

Genetic information alone becomes reley

relationships. They are simply data. As such, Genes suggest nothing about social particular moral links among the people they, they neither represent nor demand the arbiter of personhood could replace they describe. The notion of the gene as indeed time itself-with mapped sequences of morality, religion, and historyDolgin goes on to describe the genetic family as (Dolgin 2002: 544)

ception of personhood that genetic family as giving rise to a new conarranged relationships nor the modern the traditional hierarchically "families-of-choice." In this context autonomy-based relations of between the individual and the tell them apart, to distinguish one stuck in an old dyad between top-down other. Dolgin however, appears hand (hierarchically based families) and oppressive power on the one based families) on the other. There is individual power (autonomyan empowered but vulnerable and is no room in her imaginary for While I do not agree

a recuperative antipostmodern the biogenetic family represents with its failure to offer hierarchy or the autonomy model, raises an even 
which the individual cannot sustain its discomfort with the way in which the individual camnot suils to recdistinction from the group in the face of genetic inner self-evidently negognize that group membership or identification is mith a disadvantaged group ative. It only becomes so when one is aligniture, morality, religion, and hisin society. Just as the gene can replace culture, morality, disability, sexuality, tory as the arbiter of personhood, so can skin the gene is so interesting-it gender, and so on. It is for this reason that the gene is so intere who have may draw into the web of potential social disadvantage those who fo finkler managed to keep themselves out of it. In response Dolgin remarks:

[T] his construction of family ... replaces the notion of autonomous individuality Dith a notion of a larger group, defined through the metaphor of the individual a nother each other and from the but withio which each person is indist 200

Dolgin here reiterates a point she has made elsewhere that the move from group implicates "individuals assumed on other grounds individual to group ing to that group" (Dolgin 2002: 544).

For Dolgin this kind of indistinction results in the subordination of l's interests to the larger group. This is an affront to the the individual's interests to the larger grom project of liberal primacy of the liberal individual that has been the project of liberal legalism.

Both Dolgin and Finkler, along with many scholars examining familial claims to genetic information, fall prey, however, to the same inamely, that plicable assumption that it is my aim here to challenge. Namordinate our individuby giving effect to our connectedness we must subordinate our indived many ality to the claims of the community. This assumption hetwidualist and scholars to describe the debate as an argument ber instance, this has been the limcommunitarian accounts of identity. For instance, this has been the limited response to innovative scholars such as Loane Ske self by, at a minto challenge the rigidity of individualist accounts of the

imum, creating a communal familial genesiciticies?: Two appronches

In her article "Patient rights or family responsibilities? Two possible models to genetic testing" Loane Skene (1998) describes two possible mo mationfor dealing with genetic information. The first closely reflects the ran ale behind both the Australian genetic privacy and nondiscrimination based on and its U.S. counterpart-a legal, rights, privacy model-and is based on autonomy and self-determination (discussed later). The second model was developed by the Cancer Genetic Ethics Committee of the Anti Cancer Council of Victoria and is a medical and family-centered model (Skene 1998: 1 41). In this second model, it is envisaged that genetic information (and the tissue that is tested) would be shated among blood relatives. Furthermore, individuals would not have the ultimate right to "control ... their information and the use of the tissue taken for genetic testing" (Skene 1998: 24). Instead, ownership would reside in the doctor or hospital that prepared the tissue or genetic information. This is an approach that accords with the treatment of medical records in Australia (Skene 1998: 27).

Bennett and Bell, among others, have called this family-centered model communitarian and have responded by arguing that it is unnecessary because the current common and statute law allows encroachment on the rights of the autonomous individual in the extreme circumstances in which it is warranted. Instead, they prefer to rely on a notion of autonomy that encompasses one's relationship to others. Bennet and Bell suggest that the assumptions behind moves to communalize genetic information "rest on highly individualised and atomised notions of autonomy, which fail to take account of the relational aspects of the exercise of autonomy" (Bennet and Bell 2001: 158). They rely on Nedelsky's view that "autonomy is a capacity that exists only in the context of social relations that support it and only in conjunction with the internal sense of being autonomous" (Nedelsky 1989: 7). This conceptualization of relational autonomy offers a useful strategy for empowering the interconnected individual of transgressive normativity. However, Bennett and Bell do not consider such a radical revision of autonomy as requiring amendment to existing legal structures. Instead we are asked to accept the existence of this form of autonomy and to find its accommodation within the legal structures currently in place. I argue, however, that this kind of accommodation is simply not possible because it challenges the very framework that the legal structure seeks to enforce.

In contrast to Bennett and Bell, Ann Sommerville and Veronica English take communitarian theory as a way to modify liberal individualism in order to take into account the interconnectedness that genetics exposes. According to them: 
to thers are brought to the fore in the Interconnectedness and responsibility to others are brot to current ethical and gerietic sphere in a manner which seems to run counter to curnony are insuffigenetic sphere in a manner notions of individual rights and autonony are insufflegal orthodoxy. Extreme notions of individuaven interests. A more useful framecient to deal with these complex and interwoven inter a modified version of work is gained by combining notions of autonomy with a me person inevitably work is gained by which recognises decisions made by one person inevitably affect others and that an individual cannot have rights without also

that he or she has cerrain duties. (Sommervile and English 1999 : 150 )

While Bennett and Bell's relational autonomy and significant attempts to grapple English's modified communitarianism are significant attenpts to grapple with the problem of the transgressiveness of selfhood, neither is, in my view, adequate. In both versions the subversive potential of transgressivity is not realized. In Bennett and Bell's account, the mom with others an autonomous individual must accede to his or her relation make an exception. are anomalous moments for which law can always make an exception. In the normal course, however, laws must be written to protect individual and English"s choice of communitarianism, a certain kind of coherence is sought in the formation of tight bonds of responsibility and connection. Just as with Finkler, the move roward interconnection, when read through communitarian lens, is a desire to create "ties that bind."

Michael Walzer describes the transgressive as antithetical to However, Michael Walzer describes the tran an communitarianism because no commotion. In other words, the kind of transgressions, if we even call them that, that will be sustainable in the context of communitarianism are those that enanterpeneinterconnection among self-sustaining individuals that Walzer argues that tration among individuals. It is because of this that Walzer argues that a communitarian critique must be continuousiy applied as a corrective to the excesses of liberal individualism. He says:

ar do not bind us, there can be no such thing as If the ties that bind us together do nor bind us, there can be no such thing ans a community. If it is anything at all communitarian to the liberal community gression. The transgressive self is antithetical even to

which is its creator and sponsor. (Walzer 1990: 14-15)

Here we see the limits of even the kind of communitarianism most marginalized in the Sommerville and English write. Those who are most marginalized in the community are generally those who find themselves least accommodated by the social, political, and economic structures in place. They are seen as transgressive because they cannot meet the standards of selfhood in place. It is unlikely, therefore, that bonds of responsibility and duty can operate fairly to bind individuals who are struggling for a legitimate position within the community in the first place (discussed in the next section). Indeed, their insistence on membership in that community will itself be seen as disruptive.

Unruly transgressive bodies threaten the stability of the community because those bodies do not abide by its limits. Nevertheless, finding ourselves necessarily connected with, dependent upon, and vulnerable to others is in fact the state in which we all exist. The only question is where power resides in these interconnected selves. It is the operation of power moving within these inevitable interconnections that needs to be regulated.

In the next section I expose the transgressive body of the apparently autonomous individual through the use of legal discourses surrounding genetics. In particular, through some examples of failed attempts to regulate the use and disclosure of genetic information it becomes clear that an individuated and separate subject around which a cohort of legal rights and responsibilities are built is unsustainable. Rather than suppress that transgressivity, I argue we should embrace it as a starting point for dealing justly with people. We should give significant value to those identities that are not self-contained and independent but instead rely on a transgressive interconnectedness to sustain selfhood.

The Genetic Privacy and Non-discrimination Bill of 1998 (Cth) was the first major attempt in Australia to pass national legislation specifically dealing with issues arising out of the genetic biotechnologies. Its primary aim was to protect the individual's privacy rights over their genetic information and to prevent discrimination that might arise when information about genetic status is revealed. The bill failed to get the necessary support in Parliament, and the Australian Law Reform Commission, in conjuncrion with the Australian Human Ethics Committee, has now been charged with the role of reporting on the issues raised by the bill. ${ }^{6}$

This bill attempted to create a regulatory regime that dealt with not only the collection, storage, and analysis of human DNA samples and the genetic information characterized from them, but also discrimination 
that might arise generally and in employment and insurance as a consequence of disclosure of that information. The bill was based heavily on its U.S. counterpart and, as such, the emphasis was primarily on genetic privacy. However, it quickly became evident that it is very difficult to reconcile the individualist premise of privacy legislation with the nonindividual nature of genes. The nature of personal genetic information is that it is never just personal. Knowing an individual's genetic makeup means that you also know something about his or her genetic relatives. Who or what an individual is cannot be taken for granted, and in fact there is recognition of this in the bill itself, where an individual was defined as:

the source of a human tissue sample from which DNA is extracted or genetic information is characterised. The term includes a subject of genetic research and, where appropriate, includes the parent, guardian or legal representative of the individual. (Genetic Privacy and Non-discrimination Bill 1998: Clause 4)

The individual who is protected by the legislation is the individual who physically gave up the tissue for analysis. Yet as we have just seen, an individual's consent to disclosure of DNA information about him or herself may also reveal information about that person's genetic relatives. If an individual were defined in the bill in terms that recognized this interconnected status, a very different kind of legislative regime would result. A genetic relative might be able to deny access to the DNA information of an individual who had freely given his or her consent to its release. The bill would have to protect both its source and those who can be charactersized as connected to that source. Indeed, the second part of the existing definition, which includes the parent or guardian (of the source) within the terms of the individual, accepts that legally and socially the individual may not correspond to a spatially identified physically bounded subject. In this way the normative status of the transgressively embodied (inevitably connected, vulnerable, and dependent) subject takes a central position. This is a reasonably simple accommodation where the example involves intimate relatives, although many would see it as a clear violation of the rights of the autonomous individual to do with their bodily bits and pieces as they see fit. However, when the connections are more tenuous or less human, transgressivity as a norm is significantly more radical.
The submission by the University of Sydney's Faculty of Medicine to the Senate Constitutional and Legal Issues Committee inquiry into the bill, pointed out, for instance, that an ambiguity arises when an individmission is that the virated with a viral DNA. The point made in the subDNA, and the question DNA actually becomes part of the individual's is part of the individual (Lecessarily follows is whether the viral DNA research scientists whol (Leeder 1998) This is obviously of concern to viral DNA intermingled with want to conduct research and analysis of for commercial gain. From a human DNA and to exploit that research the human begins and ends appears to bective, a determination of where than, as Dolgin would have it underm impossible. In this sense rather ically transgressive understanding of huning individual autonomy, a radthe autonomy of the constanding of human identity is necessary to ensure whose DNA is intermingled with viratual involved. Obviously a person the geneticization of identity viral DNA is still a person. If we take inexorably defined out of existence extreme, we will find ourselves embraced. However, the existence unless a level of transgressivity is tration by the other.

How then does this

to Haraway's question, seek liable of individuated bodies, to refer back discrimination? The law requires its self-sufficient, and independent, but subject to be stable, autonomous, in fact a fabrication pendent, but the body as the law knows it is responses to bodily transgressions material fixity. Accordingly, legal a singular individual is artificially are generally boundary policing, and This sometimes occurs literally on carved out through juridical force. joined twins, or through the sterilizationg bodies, as in the case of con(Shildrick 1999, Karpin, 1992, 1999). Here we are exploing how it

how the law and scientists struggle to find the microlevel of genes. We see example of this struggle to identify exactly viable individual. Yet another bearing individual occurs, identify exactly who or what is the rightsdefunct bill dealing with rights surprisingly, in the section of the now (1) Where genetic information is over the DNA of a fetus. Clause 24 reads: of a person about that person's genome, the genetic analysis before the birth 
erson's biological mother but becomes the genetic intormainformation of the person's biological mother but becones the genacy and Nonwhen be she is born alive. (Geneti tion of that person when

This was perhaps the most disputed clause in the bill because its critics it failed to understand the basic difference that genes make. If, for instance, the biological mother is what is sometimes called a gesthe fetus in her womb for the metically related mother then, some would argue, it is inappropriate of genetic information about the fetus for the bill to give ownership of genetic inform could be the recipient of to her. Alternatively, the biological mothe is not genetically related to the a donor ovum, so that even though she is not genetically related to fhe fetus, it is the intent of all parties that she, as the guardian of the fentic informaand subsequent child, ought to have all rights over the gen tion pertaining thereto.

The Australian Medical Association, in their submission, further complicate fetal DNA ownership when they question the bill's choice of the biological mother as the appropriate recipient of these rights. They suggest "it is possible to identify which component of DNA, gene or chromosome is paternal and which is maternal; therefore why should the enetic information belong solely to the "biological mother"? (Australian Medical Association 1998: 345).

This medical response is interesting in light of the legal conception of fetus. Kristin Savell examines the English case of Attorney-General's Reference (No. 3 of 1994 ([1997] 3 WLR 421) where a pregnant woman was stabbed, causing the birth of a premature child who died shortly fter (Savell 2002). At each instance the court came up with a different cothe At the first instance it had no existence conceptualization of the fetus. At the fics in the in law; on appeal to the court of appeal, it was held to be parta organism sui mother; and in the House of Lords it was hecision is most interesting. generis. The basis of the House of Lords dectus Both Lord Mustill and Lord Hope rejected the argument ground was the fincr was a part of its mother on three grounds. The first ground was the tact that the genotype of a fetus consists of shared genetic material from its mother and its father. The second was the fact that an embryo could be created outside the womb, and the third was the characterization of ionship between a woman and her developing fetus as symbiotic.
What is interesting is how the court used the genetic connection with both the father and the mother as a signifier of individuality and therefore separation, rather than considering these joint contributions as giving rise to an interconnection between the genetic progenitors and the fetus.

It is clear from both the scientific and legal discourses discussed here that geneticization of identity is a kind of underpinning ideology, which means that those issues that would otherwise be determined by normal social arrangements are instead complicated and in some instances overridden by a genetic claim. The interesting twist is that in this intense classificatory activity the autonomous individual is not so much fragmented but revealed as already grafted onto others. In other words, the process of geneticization reveals the very transgressivity of our selves at the same time as genetics is touted as offering the capacity to identify us in our very uniqueness.

Having identified the ways in which genetics forces the recognition of a state of interconnection and interpenetration, I now go on to show how that interconnectivity cannot be neutralized through a legal or social regime that prioritizes a shared heritage, since this significantly underdescribes the complex interplay of power, expertise, and resource distribution in the context of genetic heritage. I show how there is a danger in looking to discourses of genetics as a way of describing interconnection because at the same moment that connection is foregrounded, it is also territorialized and racialized. Without an understanding of the transgressive in the context of the communal there will be no means by which to realign the existing inequities and power claims. In the final part of this chapter I examine the proposal by various indigenous and environmental groups for a "genetic commons" to see if this radical reconceptualization of the rights over and access to genetic information offers a partial solution.

Many have argued that the Human Genome Project (HGP), which had as its goal the mapping and sequencing of "the" entire human genome, relates to everybody while in fact relating to nobody at all. As the HGP confined its sampling to largely white, northern populations and yet premised its usefulness on the creation of a generic genome, the Human Genome Diversity Project (HGDP) was conceived as a necessary corrertive 
aimed at mapping ethnic diversity. The HGDP originally sought to collect samples from a broader range of ethnic populations. However, the project quickly became focused, not on obtaining samples from all the world's populations, but on targeting particular populations that were on the verge of disappearing, and on preserving, not the populations, but the cell lines. In other words, where the HGP created an apparently generic human genome (but where generic means primarily white and northern European), the HGDP identified marginal genetic identity (the exotic other). In these two projects we see a tension between nonterritorial "human genome" and a racially specific "community genome." The former can only claim its normative generic status by presenting the specified identities in the HGDP as marginal, small, threatened outposts of the other that cannot endanger the normativity of the generic genome.

This is why the decision by indigenous groups to object to the HGDP is so poignant. Indigenous groups represent the point of view of those whose bodily interconnection has been used as a means to subordinate them. In the context of the HGDP they are offered the opportunity to further negotiate the transgression of their bodies, while there is no recognition of the ways in which the most reliable western individuated bodies are never open to negotiation. The language of altruism, used in the context of discussions about the human genome as the common heritage of humanity, fails to take account of the myriad ways in which marginal bodies are already operating as common property. For instance, when the World Medical Association resolved that "the information [from the HGP] should be general property and should not be used for business purposes" (World Medical Association 1992), or when the guidelines to the HGDP describe its primary aim as "[u]ltimately, to create a resource for the benefit of all humanity and for the scientific community worldwide" (International Planning Workshop 1993: 4), there is a fundamental failure to understand the unequal distribution of common resources worldwide and the way that inequality is mapped along race and gender lines. The harvesting of genes from indigenous people is to be compared, for instance, with the harvesting of the genetic information of the people of Iceland, which has become both a multimillion dollar joint venture between the government and two multinational corporations
(deCode Genetics and Roche Pharmaceuticals) and a debate about nationalism and the ideology of racial purity (see later discussion).

Yet scientists involved in the HGDP are, it seems, genuinely perplexed liberal individual moded rigorous commitment to informed consent (the to group cultural model) in conjunction with a generous sensitivity of would-be participants. Victore they are rebuffed by indigenous groups describes the difference in understanding:

I was on a panel with Andre Langanay a former committee member for the conference in Berne, Switzerlect (HGDP) at the "Patents, Genes and Butterflies" I presented my critique of this project was asked to talk about the HGDP and understand what indigenous project. During the open forum he said he couldn't in order to help heneus peoples have against the extraction of their blood he argued. (Tauli-Corpuz 2001: 252)

Andre Langanay's statement shows the importance of a commitment to a situated account of identity. While Laganany sees the project as benign, Tauli-Corpuz views the project from the perspective of someone who knows all too well the power of colonizing forces to appropriate and control bodies, territories, resources, cultures, and knowledges. In the same way, the submission by the Aboriginal and Torres Strait Islander Social Justice Commissioner, Dr. Bill Jonas, to the Australian Law Reform Commission's inquiry into the protection of genetic information highlights the context in which indigenous Australians think about the extraction of genetic information from their citizenry:

As the most disadvantaged members of Australian society, Aboriginal and Torres Strait Islander peoples are especially vulnerable to exploitation. Their past knowledge, culture and the arts. Geenetic characterised by the stealing of land, are providing yet another rich. Genetic mutations found in discrete populations pharmaceutical companies acting with exploitation, this time by trans-national or state governments. (Jenas 2002.3 )

It is clear then, that

on the sharing of what is no more advocate an altruistic model premised in which individual rights already shared genetic material, than a model The HGDP Model Ethicat that shared material are enshrined.

for instance, attempts to 
collecting samples to obtain appropriate consents from the communities being sampled and to work in partnership with them (Human Genome Diversity Committee 1993: 18). At the same time, long-term storage of the information is contemplated that would enable general access to the scientific community, and the expertise to make use of that information resides squarely in the hands of that scientific community (Human Genome Diversity Committee 1993: 20, 29). The set of ethical issues enumerated in the Model Ethical Protocol indicates how researchers might return some of the benefit to the sampled population. Ethical issue no. 3 , for example, states:

Researchers should actively seek ways in which participation in the HGD Project can bring benefits to the sampled individuals and their communities. Examples of such benefits include health screening, medical treatment or educational resources (Human Genome Diversity Committee 1993: 32).

However, these gestures insist upon using a liberal individualist model of consent and profit. It is taken for granted that the means to achieve justice is through this model.

An alternative model posited by Hilary Cunningham exposes the way in which the liberal individualist model fails. She describes her model as relational and rejects a model in which the scientist and the indigenous group operate as two separate negotiating identities. Instead she posits the following:

I do not mean a traditional collaboration in which a project is designed and then implemented with the consultation of a research constituency. The collaboration which I mention here makes the scope, design, goals, methods of implementation and access to research results all negotiable items. Empirical researchers in particular, whose objectives and methods are said to be governed by acontextual laws and procedures will find this collaboration particularly difficult since it chilllenges the very epistemological basis of scientific knowledge. Such collaboration suggests that just as valuable to any project's scientific objectives is the formation of a viable relationship with research subjects. This social hermeneutic indicates that the object of research is not simply "information" (a knowledge commodity that can be acquired and controlled by one party) but "insight," a relational kind of knowledge that can be developed only through negotiation of two engalged parties. (Cunningham 1998: 227-228)

It is clear that what is being suggested here is more along the lines of my transgressive normativity model. The research subject is no longer kept at arms length but instead becomes both researcher and researched.
The boundaries between the two, no longer strictly held, challenge the way in which western research is standardized or apparently made objective. Cunningham recognizes the radicalness of this position when
she says:

Yet how many granting agencies-especially in the sciences-would be willing to the negotiation of research and mods were so fundamentally contingent upon 227-228)

It is the power plays of interconnection that are operational when, for example, the target of research is not a disenfranchised indigenous, for but a group who, in racialized terms, identify themselves with the norm and in so doing posit the purity of their genetic pool as an indicator of superiority. I am referring to the genetic database of the Icelandic population constructed by deCode in collaboration with Roche Pharmaceuticals. In this case, the subjects of the research-the Icelandic popmaceutithrough their government represe which the research would representatives-negotiated the terms under the Health Database Act take place. Arguably the Icelandic statutes, sent a substantial governme 1998 and the Biobanks Act of 2000, repreThe opt-out form of appropriate method of a fair and was explicitly legistated in boining research subjects, was something that whether the results and in both acts. ${ }^{7}$ While controversy continues over of a private corporation the research should be in the hands deCode under the lation, the fact remains that the license provided to are not unconnected researion is for twelve years only. Icelanders then, in which the reare rearch subjects, but have had a san the manner to ensure that some of in place provisions Iceland. yet indigenous groups then why Iceland has been able to do this and has characterized the deted by the HGP have not. Skuli Sigurdsson research population dor around the advantage of Iceland as a myths, clichés, fan invocation of and regurgitated half-truths" as having "hardly left a dent " He identifies the eugenic past of Iceland 
That past, however, is quite significant. Finnbogason, one of the most influential Icelandic intellectuals of the first half of the twentieth century, invoked the "science of eugenics" to argue for the "purification of the Icelandic race to preserve its spiritual and physical assets" (Palsson and Harðardóttir 2002: 282). Einar Arnason, professor of evolutionary biology and population genetics at the University of Iceland, has made similar statements about the way that the deCode project has "evoked the myth of the homogen[e]ous Aryan Icelanders" (Arnason, 1999) and has challenged those claims with research suggesting that Iceland is one of the most genetically heterogeneous nations in Europe (Arnason et al. 2000: F3).

What we are left with then is two different kinds of interconnected communities. The Icelandic community has to some degree (although within the bounds of an all too inadequate democratic governance) ensured that the power plays over their interconnectivity do not result in their exploitation. Here their connectivity does not undermine their power but instead gives effect to it. However, in the case of indigenous communities, their connectivity is negated by the requirement for individual consent imposed by researchers coming from western legal traditions that favor the autonomous individual. These groups then find themselves with seemingly no legal recourse for protection of their genetic information as a group.

\section{Conclusion}

My aim in this chapter has been to utilize genetic discourses to challenge the stability of the autonomous and individuated liberal self. I have done this in order to open a space for subjects who are connected, vulnerable, and dependent and who cannot shed their dependencies in order to become the liberal subject. These are the people whose very selfhood is then seen as unruly and threatening. Once we have taken as a base unit the interconnected self, regulatory effort will need to be directed to determining where power resides in these interconnected selves. This is in contrast to the call for a "genetic commons" which, while offering the genome and genetic discourses as a resource held in common to be used equally by all people, will not be successful unless some further account is taken of the unequal society onto which such a commons must be mapped. The treaty initiative to share the "genetic commons" that was formally launched in February 2002 at the World Social Forum in Porto Alegre, Brazil, reveals this tension in its text, which states:

Therefore, the nations of the world declare the Eart's gene pool, in

logical forms and manifestations, to be a the Earth's gene pool, in all of its bionurtured by all peoples and further declare that commons, to be protected and for, in their natural, purified or synthesized form as and the products they code tissue, organs and organisms, included cloned as well as chromosomes, cells, isms, will not be allowed to be claimed cloned, transgenic and chimeric organmation or intellectual to be claimed as commercially negotiable generic inforinstitutions or individuals. (Treaty to Share the Commercial enterprises, other (Treaty to Share the Genetic Commons 2002: 6)

However, in the explanatory material that accompanies the text, the of communities to exchange or support the sovereignty of nations and trust. ... We wish to affich or withhold genetic materials they hold in as well as the right of individuational sovereignty and community rights crimination (Treation ... to have their own genetic integrity and rights ensured" (Treaty to Share the Genetic Commons 2002).

It is this tension that $I$ have been discussing throughout this chapter. How do we assert our autonomy over our genetic integrity yet recognize our of the self that is transgressive thats? I argue that if we have an account an other at once, an other at once, we offer a self that is vulnerable to the interests and incurdate this newly dependent being sensitive to them. The law must accommothe treaty are trying to accomplonnected self. It is this that the authors of

and Indigenous Peoples a "caretaker" of is designed to make every government genetic commons and to "caretaker" of their geographic part of the global ensure both national sovereignty and open access to statutory mechanisms to tion. (Treaty to Share the Genetic Commons 2002: the flow of genetic informa-

In this statement we have an attempt to bring together the traditionally
opposed positions of self-sufficiency and depend arguing is that the concept of the idealized indence. What I have been legalism is challenged by of the idealized individual of western liberal this as an assault, we should embrace the transgressivity of all selves. 
In so doing, those traditionally disempowered by a vulnerable and uncontained selfhood would find some recourse in the law.

\section{Notes}

1. Lacan cites Roger Callois's essay "Mimicry and Legendary Pyschaesthenia" to explain how the formation of the ego has its origins in a process of depersonalization by assimilation to space (Lacan, 1977). See also Meek's discussion of this point (Meek 1998).

2. This term is borrowed from Shildrick (1997).

3. Geneticists distinguish between a pedigree, which is a representation of biological relatedness, and a family, which is the named, identified collection of individuals defined in terms of their kinship relations with one another.

4. In one case, for example, "Eve noted she felt closer to her sister and husband and her father but had also become closer to her cousins" because they shared a genetic susceptibility to cancer.

5. In Finkler's response to her critics she notes, "I prefer to use the concept of hegemony of the gene instead of geneticization because the Gramscian construc of hegemony encompasses the concept of the power of dominant institutions to impose an ideology by their very authority which permeates the social and cultural fabric of daily life, without the use of force" (Finkler 2001: 257).

6. The Australian Law Reform Commission and the Australian Health Ethics Committee released a final report, discussion paper 66, 'Protection of Human Genetic Information,' in August 2002.

7. Icelanders were given the right to opt out of the database, but until they do so, they are presumed to have opted in. This was further entrenched in the BioBanks Act, which was passed in May 2000 without any public discussion (Sigurdsson, 2001). By the middle of March 2001, 19,697 citizens had opted out of the HSD and as Sigurdsson describes it, "in the process become entities in a second-order HSD, registering those socially deviant whereas the first-order HSD is still empty" (2001: 113).

\section{References}

Arnason, Einar (1999) Letter to the editor, New York Times, February 15. Available at http://www.mannvernd.is/english/articles/ea.nytimes.html.

Arnason, Einar, Sigurgislason, Hlynur, and Benedikz, Eirikur (2000) "Genetic Homogeneity of Icelanders: Fact or Fiction?" Nature Genetics 25: 373-374.

Australian Medical Association (1998) "Submission no. 24" to the Senate Legal and Constitutional Legislation Committee on the Genetic Privacy and NonDiscrimination Bill 1998, vol. 2, p. 345. Ballard, Susan (2001) "My viewing body does not end at the skin", Available at
http://www.voyd.com/ttlg/textual/ballardessay.htm 2001 .

Bennet, Belinda, and Bell, Dean (2001) "Genetic Secrets and the Family," Medical
Law Review 9: 130-161.

Shepley, October 31 (Winter): 17-33 Legendary Psychaesthenia," trans. John

Cunningham, Hilary (1998) "Colonial Encounters in Postcolonial Contexts Patenting Indigenous DNA and the Human Genome Diversity Project," Critique
of Anthropology 18 (2): $227-228$.

Dolgin, Janet (2002) "Choice, Tradition and the New Gentics: The of the Ideology of the Family, "Connecticut the New Genetics: The Fragmentation Finkler, Kara (2001) “The Kin in

235-263. Genetic Privacy and Non-discrimination Bill 1998 (C th).

Haraway, Donna (1991) Simians, Cyborgs and Women.

Human Genome Diversity Committee (1993) Sumbary. New York: Routledge. Planning Workshop, Sardini (1993) Summary Report of International http://www.stanford Sardinia (Italy) 9-12 September 1993. Available at 12 October 2004). International Plangir

Summary Document" Workshop (1993). "Human Genome Diversity Project. summary93.html @30/8/02. Jonas, Bill, (2002) (A

missioner, HREOC) "The Protection Torres Strait Islander Social Justice ComPeoples." Submission to the Australian of Genetic Information of Indigenous the protection of genetic information" social_justice/genetic_information.h Available at http://www.humanrights.gov.au/ Karpin, Isabel (1992)

and the Reconstructed Woman" $3(1): 325-349$.

Karpin, Isabel (1999) the Bodies of Women with Disabilities" in the Eyes of the Body: Regulating Diversability and Legal Change. The," in L. A. Marks, (ed.), Disability, Publishers.
Lague: Kluwer International Law, Lacan, Jacques (1977) Ecrits: A Selection, trans. Alan Sheridan. New York:
W. W. Norton.

Leeder, Stephen (1998) Faculty of Medicine and the Centre for Values, Ethics and the Law in Medicine, University of Sydne "Sub Centre for Values, Ethics and and Constitutional Legislation Committee "Submission no. 3" to Senate Legal Discrimination Bill 1998, vol. 1, 9 . Meek, Allen (1998) "Benjal. 1, p. 9

at http://www.latrobe.edu.au/screeningthepal and the 'fascistic subject'." Available 
Nedelsky, Jennifer (1989) "Reconceiving Autonomy: Sources, Thoughts and Possibilities," Yale Journal of Law and Feminism 1:7-36.

Palsson, Gisli and Harðardóttir, Kristín (2002) "For Whom the Cells Toll: Debates About Biomedicine," Current Anthropology 43(2):271-302.

Ronell, Avital (1989) The Telephone Book: Technology, Schizophrenia, Electric Speech. Lincoln: University of Nebraska Press.

Ronell, Avital (1994) "The Walking Switchboard," in Finitudes Score: Essays for the End of the Millenium. Lincoln: University of Nebraska Press.

Savell, Kristin (2002) "The Mother of the Legal Person," in S. James and S. Palmer (eds.), Visible Women: Essays on Feminist Legal Theory and Political Pbilosophy. Oxford: Hart, pp. 44-46.

Shildrick, Margrit (1977) Leaky Bodies and Boundaries: Feminism, Postmodernism and (Bio)ethics. London: Routledge.

Shildrick, Margrit (1999) "This Body Which Is Not One," Body and Society 5(2/3): 77-92.

Sigurdsson, Skuli (2001) "Yin-Yang genetics, or the HSD deCODE Controversy," New Genetics and Society 20 (2): 113-117.

Skene, Loane (1998) "Patient's Rights or Family Responsibilities? Two Approaches to Genetic Testing," Medical Law Review 6:1-41.

Sommerville, Ann, and English, Veronica (1999) "Genetic Privacy: Orthodoxy or Oxymoron?" Journal of Medical Ethics 25:144-150.

Tauli-Corpuz, Victoria (2001) "Biotechnology and Indigenous Peoples," in Brian Tokar (ed.), Redesigning Life : The Worldwide Challenge to Genetic Engineering. London: Zed Books.

Treaty to Share the Genetic Commons. (2002) Available at http://www. antivivisezione.it/TreatyRifkin.html.

Walzer, Michael (1990) "The Communitarian Critique of Liberalism," Political Theory 18(1):6-23.

World Medical Association Declaration on the Human Genome Project (1992). Adopted by the 44th World Medical Assembly, Marbella, Spain. Available at http://www.wma.net/e/policy/96.htm. 